International Journal of Agriculture, Environment and Bioresearch

Vol. 5, No. 02; 2020

ISSN: $2456-8643$

\title{
DOES CLIMATE VARIABILITY MATTER FOR FOOD SECURITY IN INDONESIA?
}

\author{
Dewi Nur Asih \\ Faculty of Agriculture, Tadulako University, City of Palu, Indonesia \\ Jl. Soekarno-Hatta KM.9, Tondo, Mantikulore, Kota Palu, Sulawesi Tengah 94148, Indonesia \\ https://doi.org/10.35410/IJAEB.2020.5485
}

\begin{abstract}
This study investigates the determinants of household food security in Indonesia, with particular emphasis on climate variability. The panel data at the household level combined with rainfall and temperature data from 2001 to 2006 for a sample of households living in Central Sulawesi at the rainforest margin, Indonesia. The principal component analysis applied to develop an indicator of food security and a panel econometric model to study its determinants. The findings suggest that rainfall, temperature, area cultivated, access to credit and household human capital measured by age, maximum education and household size are the main drivers and thus determinants of household food security over time. Climate variation in rainfall and temperature, as well as household size, negatively affects food security. In particular, the variability in rainfall leads to declines of $33 \%$ and $15 \%$ in the availability and stability of food in the household, respectively. While increasing the area cultivated, access to credit, the household's age and the family's education level are the main factors promoting food security over time.
\end{abstract}

Keywords: Climate Variability, Food security, Rural Household, Indonesia.

\section{INTRODUCTION}

Climate change, as well as rising food and energy prices, can undermine food security globally, but even more so in developing countries. According to projections by the Intergovernmental Panel on Climate Change (IPPC), global temperatures could increase by $\sim 4^{\circ} \mathrm{C}$ or more above mid-18th-century levels by 2100 , which combined with increasing food demand, would pose large risks to food security globally and regionally. All aspects of food security are potentially affected by projected reductions in food supplies, income, and employment (IPCC, 2014). Climate-induced changes in agricultural productivity can occur through crop failure, new patterns of pests and diseases, lack of appropriate seeds and planting material, and the loss of livestock, which all lead to a reduction in food production (FAO, 2008). As a result, local food prices may increase, reducing rural incomes and rising poverty, particularly for poor households who are net buyers of food. The negative effects will threaten the livelihood of poor people as well as the respective economic, ecological and political climate. Due to the heavy dependence on the agricultural sector for their country's economy and poverty levels, some studies have asserted that the potential impacts will be severe and particularly pronounced in developing countries (IPCC, 2014; Benson and Clay, 1998).

Indonesia is likely to be affected by the additional challenges that will be brought on by global warmings, such as increasing temperatures, intense rainfall, and rising sea levels, which 
will threaten food security and poverty alleviation (Measey, 2010). Indonesia is also the fifth most populous country in the world with a total population of 254.5 million. Most of this population lives in rural areas and depends on agriculture for their income and livelihood. The agricultural sector makes up the second-largest share of GDP of the country, accounting for 15.30 per cent of total GDP, which employs 40 per cent of all rural workers (Netherlands Commission for Environmental Assessment, 2015; Food Security Council and WFP, 2015). The workers engaged in the agriculture sector generally work in the cultivation of staple foods (rice), cash crops (rubber, coconut, cocoa, palm oil, and coffee), poultry and fishing and are already faced with climatic challenges. Therefore, any irregularities in climate patterns may lead to serious consequences and pose serious problems to agricultural production as well as the growth and development of the country.

Considering that millions of poor households in the rural areas of Indonesia are dependent on agriculture, these adverse conditions can have substantial negative effects on income through agricultural production that will threaten food security in the country. Therefore, this study aims to highlight the vulnerability of the food security problem in rural areas in Indonesia. The underlying research questions are:

1. What are the factors influencing food security of rural households in Indonesia?

2. To what extent does climate variability influence the persistence of food security over time?

\section{MATERIALS AND METHODS}

\subsection{Data}

The study used three-year panel data collected in 2001, 2004 and 2006 under the Stability of Rainforest Margins in Indonesia (STORMA) project in Central Sulawesi, Indonesia. The surveys covered 257 households for each year, selected randomly from 13 different villages in the vicinity of the Lore Lindu National Park in Central Sulawesi, Indonesia. Moreover, the household socioeconomic data were combined with the climate data on temperature and rainfall obtained from the climate stations of STORMA. The information is comprised of historical climate conditions from 2001 to 2007, which was collected from 11 different climate stations across the villages to represent the climate condition of the research areas.

\subsection{Data Analysis}

To analyze the link between the effects of climate variability on the food security of households in rural areas of Indonesia, first a food security index constructed using Principal Component Analysis. This analysis has been used widely in several studies. For example, the Mexican government has used principal components for decades to create a marginality index for planning purposes (Skoufias et al., 2001). Filmer and Pritchett (1998) used principal components to construct a household level asset index as a proxy for wealth. In this study, the principal component analysis method proposed by Demeke et al (2011) is used to develop a food security index. Mathematically, PCA creates uncorrelated indices or components, whereby each component is a linear weighted combination of the initial variables a set of variables $\mathrm{X} 1$ through to $\mathrm{Xn}$, as follow

$$
\mathrm{PCm}=\mathrm{am} 1 \mathrm{X} 1+\mathrm{am} 2 \mathrm{X} 2+\mathrm{am} 3 \mathrm{X} 3+\ldots+\operatorname{amnXn}
$$


Where amn represents the weight for the mth principal component and the nth variable, which are the weight of respective food security variables identified (focusing on the three dimensions availability, accessibility and the stability of food) and $\mathrm{X} 1, \mathrm{X} 2, \ldots \mathrm{Xn}$, are the food security-related variables. The food security index is following the formula from Filmer and Pritchett (1998) as seen below:

$$
\begin{aligned}
& \mathrm{FSj}=\mathrm{F} 1(\mathrm{Xj} 1-\mathrm{X} 1) / \mathrm{S} 1 \ldots \mathrm{FN}(\mathrm{XjN}-\mathrm{XN}) / \mathrm{SN} \text {; or } \\
& \mathrm{FSIj}=\sum \mathrm{Fi}[(\mathrm{Xij}-\mathrm{Xi} / \mathrm{Si} 0] \ldots \ldots \ldots \ldots \ldots \ldots \ldots \ldots \ldots \ldots \ldots \ldots \ldots
\end{aligned}
$$

Where FSIj is the food security index and follows a normal distribution mean of 0 and a standard deviation of 1 . Fi is the weight of the ith variable in the PCA model. Xij is the jth household's value of the ith variable. Xi and Si are the mean and standard deviations of the ith variable for all households.

\subsection{Factors determining food security status}

A panel data model applied to examine the impact of climate shocks and factors influencing on food security in the research area. The panel data model combined cross-sectional and time-series data related to the factors influencing food security and the indicators used to measure food security. For this purpose, climate variability and household demographic characteristic were correlated with food security and use three rounds of household panel data sets:

$$
\text { Yit }=\delta+\beta \text { Xit }+\alpha i+\varepsilon i t
$$

Where $\mathrm{Y}$ is food security (Index from PCA above), $\mathrm{X}$ is the matrix of variables in a household (i) at a period ( $\mathrm{t}$ ), including our variables of interest and other control variables, eit is the error term, and ai represents the household fixed effect. Moreover, two measurements used to identify potential heterogeneity in the relationship between climate variability, household demographic characteristic, and food security. First, to explore the determinants of household food security and second the impact of the climate variability to the persistence of food security over time, it correlated the expected food security index from the Principal Component Analysis as an indicator plus household demographic characteristics. The variable of interest that we added is the annual variability of rainfall and temperature measured by the annual mean and standard deviation. It assumed that the current values of food security determined by the value of the explanatory variables, thus the current food security status of the households predicted by regressing them in the system with the variables of interest.

$$
\mathrm{FSI}_{\mathrm{it}}=\delta+\beta 1 \mathrm{X}_{\mathrm{it}}+\gamma 1 \text { rainfall }+\gamma 2 \text { temperature }+\alpha \mathrm{i}+\varepsilon \mathrm{it}
$$

Where $\mathrm{Y}$ is Food security, $\mathrm{X}$ represents our control variables (age, sex, household size, schooling, number of men, dependency ratio) in a household (i) at a period (t) and our interest variables stand for the variability of rainfall and temperature. eit is the error term and ai represents the household effect. The model (equations 3 to 4 ) is estimated using the Ordinary Least Squares (OLS) method. However, this estimator is biased because it does not take into account the unobserved heterogeneity of the households. Thus, we first need to transform all of the variables into panel data to be capable of uncovering group effects, time effects, or both of 
the factors influencing food security over time. This allows us to apply Fixed Effects (FE) and Random Effects (RE) estimators. The fixed effects approach assumes that $\alpha \mathrm{i}$ is treated as nonrandom and hence makes the correlation between the observed explanatory variables (Xit) and $\alpha \mathrm{i}$ possible; the random effects approach is applicable under the assumption that $\alpha \mathrm{i}$ is random and not correlated with Xit and puts it into the error term (Wooldridge, 2002). We used the Hausman test to check the suitability of the model specification between these models. If the result has an insignificant P-value, Prob $>\chi 2=0.9999$ or larger than 0.05 , it means that it is appropriate to use the random effect estimator. However, if the P-value is significant, we must use the fixed effect estimator.

\section{RESULTS AND DISCUSSIONS}

\subsection{Socioeconomic Characteristics of the Households}

Descriptive evidence from the surveys shows that the average household head in the research area is in a productive age with an average age of 46 years (Table 1). The results also indicate that 94 per cent of the households were male-headed, with the education level of the household head being at level 2 , which indicates that household heads are illiterate with only a partial primary school education. Moreover, the average maximum education of family members is 4.6 years, which is equal to the level of secondary school. Higher levels of education can promote food security, particularly via the ability to earn a higher income. Being literate will therefore likely increase the chance of being food secured.

Table 1. Summary statistics of household's characteristics

\begin{tabular}{|lll|}
\hline Variable & Mean & Characteristic \\
\hline Age & 46.29 & Age of household head \\
& $(13.87)$ & \\
Sex & 0.94 & Sex of household head $(1=$ male, $0=$ female) \\
& $(0.21)$ & \\
Schooling of $\quad$ HH & 1.64 & Year of schooling household head \\
Head & $(0.55)$ & \\
Household Size & 6.1 & No of household members \\
& $(2.42)$ & \\
Dependency Ratio & 0.89 & No of economic non active hh member (age \\
& $(0.75)$ & <15 or $>65)$ \\
Number of men & 1.39 & No of men in household \\
\hline
\end{tabular}




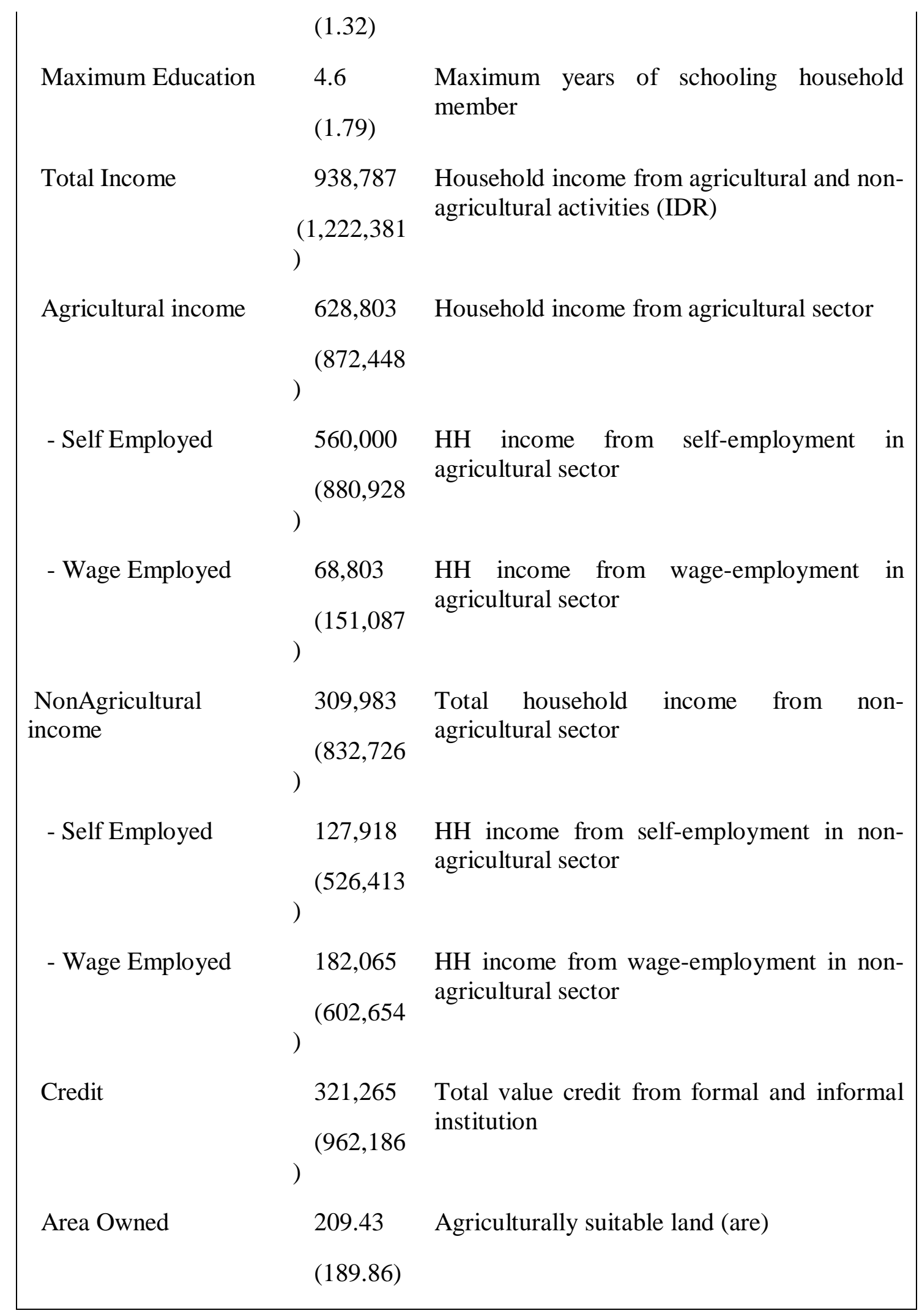


- Area Cocoa

- Area Coffee

$$
\text { - Area Rice }
$$$$
\text { Area Coffee }
$$

- Area Others

Mean Rainfall

Rainfall Variability

Mean Temperature

Temperature

Variability

Visit of Extension 0.32 officer

Electricity

Access to drinking water

Access to toilet

\section{(2.01)}

24.46

0.87

0.66

0.39

0.62

$(0.48)$

Flooring
0.79
Agricultural land planted with cocoa

Agricultural land planted with coffee

Agricultural land planted with rice

Agricultural land planted with other crops (vegetable and fruits).

Yearly mean rainfall

Deviation of rainfall (yearly)

Yearly mean temperature

Deviation of temperature (yearly)

Household received agricultural service (1=yes, $0=$ no)

Household connected to electricity (1=yes, $0=$ no)

Household access to drinking water (1=yes, $0=$ no)

Household access to toilet ( $1=$ yes, $0=$ no)

Household floor condition (1=traditional, 2= modern) 


\begin{tabular}{|lll|} 
Roofing & $(0.41)$ & \\
& 0.80 & $\begin{array}{l}\text { Household roof condition (1=traditional, 2= } \\
\text { modern) }\end{array}$ \\
\hline $\mathrm{N}$ & $(0.40)$ & \\
\hline
\end{tabular}

Source: Author's calculation from the survey data. Standard deviation is in parentheses. Local lands unit are measured in Are $\left(1\right.$ Are $\left.=100 \mathrm{~m}^{2}=0.01 \mathrm{ha}\right)$.

Furthermore, the survey shows a high number of households with a size of around six members and a dependency ratio of 0.89 /household, with 1.39 men on average. In light of these preliminary results, it was hypothesized that household size and the number of men will affect the chance of being food secure, as they can be more productive and active in generating incomes as well as producing food directly. These demographic factors could affect household food security status and it is expected to have a positive relationship.

The mean annual income per capita of households is 938,787 (IDR) where farm activities contributed $67 \%$ of the total average annual income, generated from agricultural self and wage employment, which accounted for 560,000 IDR and 68,803 IDR, respectively. On the other hand, off-farm activities contributed 33\% where nonagricultural self-employment and nonagricultural wage employment are 127,918 IDR and 182,065 IDR per month, respectively. Furthermore, households in the research area used credit access both in cash and in-kind for consumption and/or production purposes. The average amount of credit that was consumed was 321,265 IDR provided by either formal institutions, such as commercial banks, or informal means such as private money lenders, input dealers, traders, landlords, friends, and relatives. Particularly for the sample households, most of whom are small-scale farmers, credit was used to increase the chances of acquiring productive resources (seeds, fertilizers, pesticides and others), which will help boost productivity and improve the food situation of the family.

From the productivity side, the average landholding per household is 209.43 Are, of which 93.68 Are (45\%), were used to cultivate the cash crop cocoa, followed by 29.69 Are (14.36\%) for coffee cultivation, and 26.78 Are $(12.95 \%)$ is used for rice cultivation -a staple food. The remaining 56.59 Are (27.38\%) are used for growing other kinds of plants such as vegetables, fruits and various legumes where households grow carrots, potatoes, maize, cassava, avocados and bananas. Some households combined the crops with the cultivation of coconut, peanuts, beans and other crops as well. Given the important role of agriculture, it is surprising to see that only $32 \%$ of households met and received agricultural services, meaning that their remains a large need in the improvement of extension services to promote agricultural development in the area.

Moreover, the health status of households is in overall bad condition. Although more than 60 per cent of the households have better access to a toilet, are connected to the electric grid and maintain their house with better flooring and roofing, $61 \%$ of households do not have access to safe drinking water, $38 \%$ report being without a toilet facility, $21 \%$ have floored the house with 
bamboo, wood, or do not have any material on the floor. This condition implies that the health status of households can be summarized as being in poor condition.

\subsection{The variability of the climate data on temperature and rainfall}

Figure 12 shows a marked variation of temperature conditions in the different regions for the years 2001-2007. Based on the daily data, the temperature data collapsed into monthly data to measure the condition during the years. The data shows that the temperature is fluctuating in the range of $23^{\circ} \mathrm{C}$ to $24^{\circ} \mathrm{C}$ where the temperature in those areas in average around $24^{\circ} \mathrm{C}$ deviates between $0.76^{\circ} \mathrm{C}$ to $0.89^{\circ} \mathrm{C}$ over the years.

Figure 1. The mean and standard deviation of temperature over the year $2001-2007$
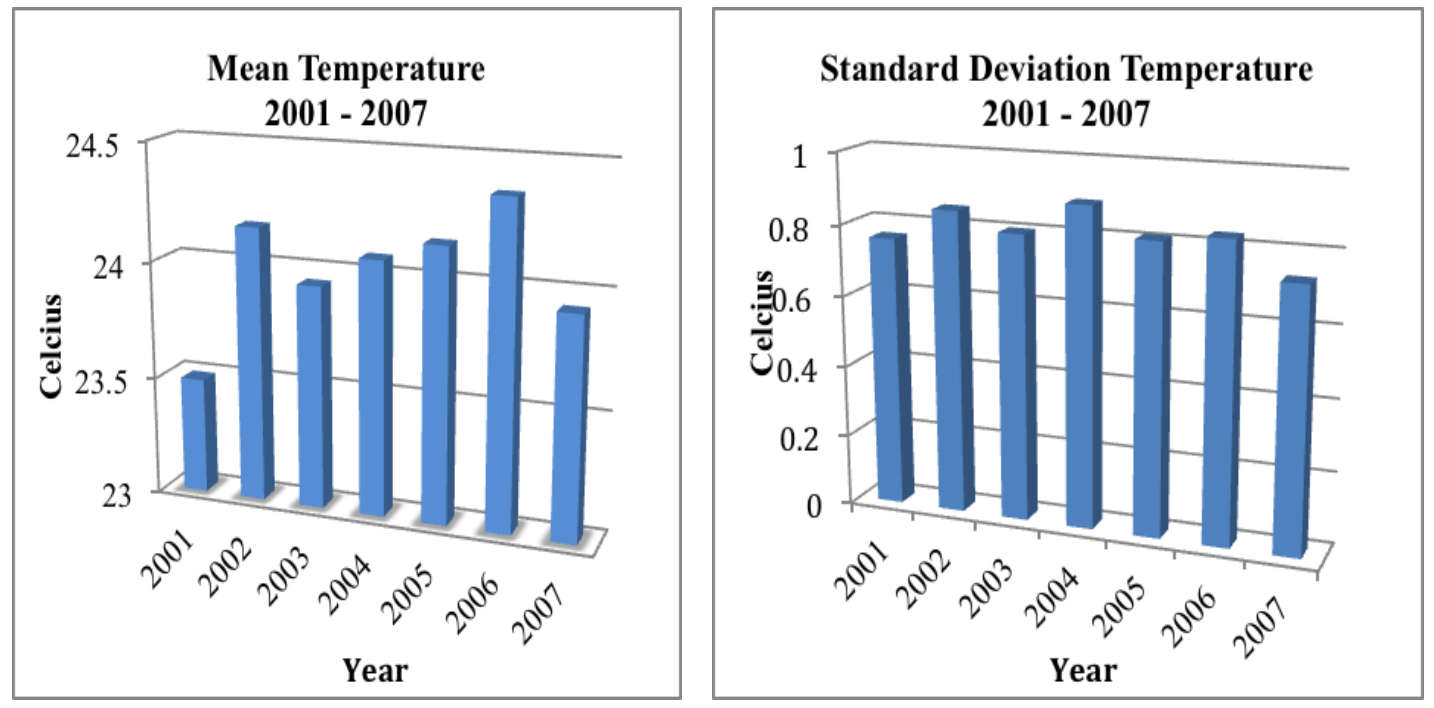

Source : Author calculation based on climate data

Meanwhile, through the same procedure, we calculate rainfall conditions in the research area. Figure 2 shows the variability of rainfall in the regions, as posted by each station during the survey periods in 2001 - 2007. Overall rainfall presents a wide fluctuation in the range of 3.67 $5.22 \mathrm{~mm} / \mathrm{month}$, with a marked declined of $0.94 \mathrm{~mm}$ shown in 2004 (from 5.11 to $4.17 \mathrm{~mm}$ per month in 2003), as well as showing the deviation declining significantly from 8.73 to 7.45 $\mathrm{mm} / \mathrm{month}$ between the years 2003 to 2004 , before it continues to fluctuate, and then receiving the highest intensity of $5.22 \mathrm{~mm}$ per month in 2007. 


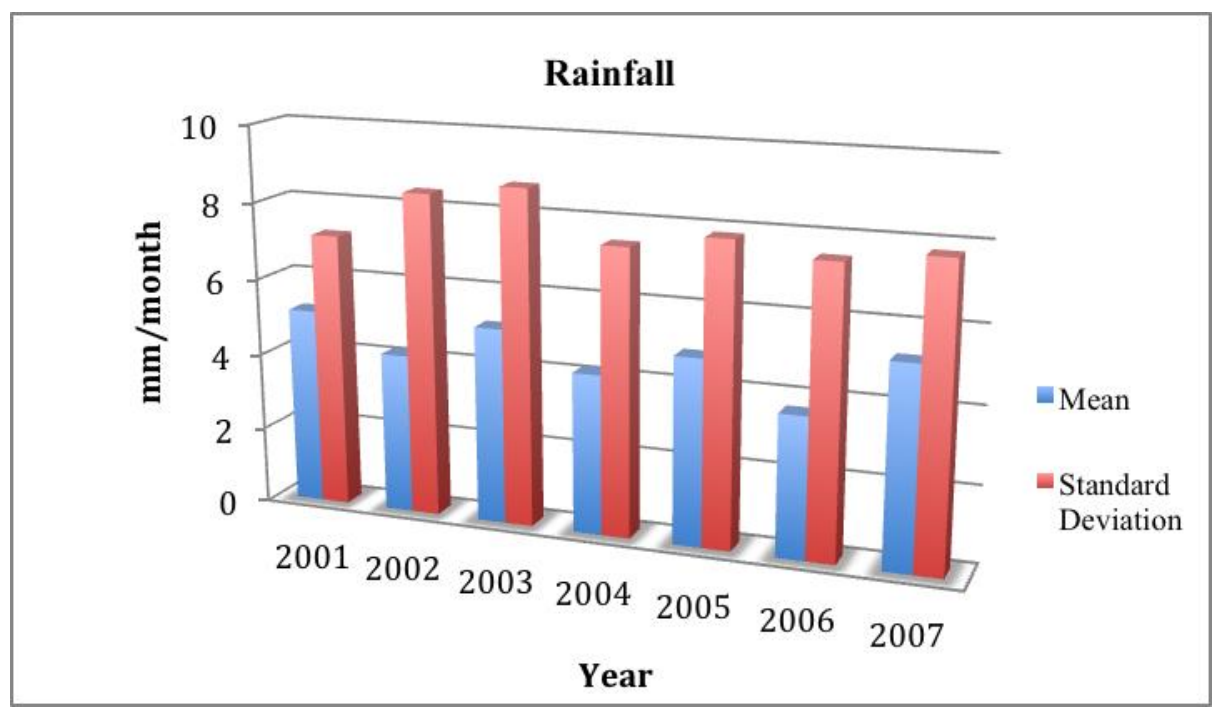

Source: Author calculation based on climate data

This indicates that the research area is experiencing a change in temperature and rainfall patterns, which may have a significant impact on household crop productivity since the sector is vulnerable to climate changes. Syaukat (2011) studied the impact of climate change on food production and security as well as its adaptation programs in Indonesia. It found that Indonesia's agricultural production is more sensitive to temperature increases than rainfall decreases. However, both rainfall and temperature changes are indicators of the potential climate change that could have direct and indirect effects on crop productivity, which consequently affect the overall human welfare in the country.

\subsection{Food Security Index}

The PCA result shows that the model was adequate $41.83 \%$ in explaining variation food security condition of the households. Given 0.5365 values of the Kaiser Meyer Olkin (KMO) measures of sampling adequacy, means 53\% level of correlation between the pairs of components, which can be explained by the other variables in the index. These results indicate a positive correlation with the food security hypothesized for all components used. Therefore, the first component is considered to be the index of food security of the households, which captures the greatest information from the given variables. This result is in line with the research by Asih and Klasen (2017).

Moreover, PCA result also shows the component loading of food security indicators (food production, cash crop and non-farm income and land value). As expected, the indicators show a positive sign, which is significant in explaining the variation of food security in the research areas. Furthermore, to what extent the food security index correlates with the indicators, the correlation of food security index over the indicators then was tested through the Pearson correlation analysis. Given the positive sign of Pearson's analysis $(|\mathrm{r}|>.5)$; it shows a strong correlation between the component and the index; means all the food security indicator are reliable and interconnected with each other. The result indicates that all variables used; food 
Vol. 5, No. 02; 2020

ISSN: $2456-8643$

production, cash crops, and non-farm income, as well as land value, represents important complementary dimensions of household food security.

\subsection{Econometrics Specification}

The determinants and the effects of climate variability on food security using different econometric methods are presented in Table 2 and 3. Based on the food security index, the results allowed interpreting the condition of household food security through the sign of the coefficients and their relative magnitude.

Table 2. Determinants of food security and the indicators of food security

\begin{tabular}{|c|c|c|c|c|}
\hline \multirow[t]{3}{*}{ Control } & Food & \multicolumn{2}{|c|}{ Indicator of Food Security } & \multirow[b]{2}{*}{ Stability } \\
\hline & & Availability & Accessibility & \\
\hline & (1) & (2) & (3) & (4) \\
\hline Age & $\begin{array}{l}0.0105^{* *} \\
(0.0041)\end{array}$ & $\begin{array}{c}0.0146^{* * * *} \\
(0.0045)\end{array}$ & $\begin{array}{l}-0.0074 \\
(0.0058)\end{array}$ & $\begin{array}{l}0.0111^{* *} \\
(0.0045)\end{array}$ \\
\hline Sex & $\begin{array}{l}0.0176 \\
(0.0336)\end{array}$ & $\begin{array}{l}0.0470^{*} \\
(0.0284)\end{array}$ & $\begin{array}{l}0.1069 * * * \\
(0.0302)\end{array}$ & $\begin{array}{r}-0.0470 \\
(0.0393)\end{array}$ \\
\hline Max. Education & $\begin{array}{l}0.1460 * * * \\
(0.0322)\end{array}$ & $\begin{array}{l}0.0923^{* * * *} \\
(0.0337)\end{array}$ & $\begin{array}{l}0.1639 * * * \\
(0.0372)\end{array}$ & $\begin{array}{l}0.0869 * * \\
(0.0376)\end{array}$ \\
\hline Household size & $\begin{array}{l}0.0828 * * * \\
(0.0294)\end{array}$ & $\begin{array}{c}- \\
0.0945^{* * *} \\
(0.0326)\end{array}$ & $\begin{array}{l}-0.1114 * * * \\
(0.0301)\end{array}$ & $\begin{array}{c}- \\
0.0942 * * * \\
(0.0325)\end{array}$ \\
\hline $\begin{array}{l}\text { Dependency } \\
\text { ratio }\end{array}$ & $\begin{array}{c}-0.0742 \\
(0.0901)\end{array}$ & $\begin{array}{l}0.1379 \\
(0.0926)\end{array}$ & $\begin{array}{l}-0.2053 \\
(0.0974)\end{array}$ & $\begin{array}{r}-0.2470 \\
(0.0969)\end{array}$ \\
\hline Number of men & $\begin{array}{l}-0.0622 \\
(0.0708)\end{array}$ & $\begin{array}{r}-0.0071 \\
(0.0736)\end{array}$ & $\begin{array}{l}-0.0004 \\
(0.1004)\end{array}$ & $\begin{array}{r}-0.1524 \\
(0.0744)\end{array}$ \\
\hline Access to credit & $0.0542 * * *$ & 0.0252 & $0.0861 * * *$ & $0.0398 * *$ \\
\hline
\end{tabular}


International Journal of Agriculture, Environment and Bioresearch

Vol. 5, No. 02; 2020

ISSN: $2456-8643$

\begin{tabular}{|c|c|c|c|c|}
\hline & $(0.0154)$ & $(0.0176)$ & $(0.0235)$ & $(0.0180)$ \\
\hline Area cultivated & $\begin{array}{l}0.0015^{* * * *} \\
(0.0003)\end{array}$ & $\begin{array}{l}0.0016^{* * * *} \\
(0.0003)\end{array}$ & $\begin{array}{l}0.0016^{* * * *} \\
(0.0004)\end{array}$ & $\begin{array}{l}0.0013^{* * *} \\
(0.0002)\end{array}$ \\
\hline Mean Rainfall & $\begin{array}{l}0.1047 \\
(0.1175)\end{array}$ & $\begin{array}{c}- \\
0.6444 * * * \\
(0.1280)\end{array}$ & $\begin{array}{l}-0.1159 \\
(0.1843)\end{array}$ & $\begin{array}{c}- \\
0.2613^{* * *} \\
(0.1121)\end{array}$ \\
\hline SD Rainfall & $\begin{array}{c}- \\
0.1947 * * * \\
(0.0597)\end{array}$ & $\begin{array}{c}- \\
0.3337^{* * *} \\
(0.0629)\end{array}$ & $\begin{array}{l}-0.0797 \\
(0.0748)\end{array}$ & $\begin{array}{l}-0.1489 * * \\
(0.0586)\end{array}$ \\
\hline $\begin{array}{l}\text { Mean } \\
\text { Temperature }\end{array}$ & $\begin{array}{l}0.0070 \\
(0.0266)\end{array}$ & $\begin{array}{l}0.0432 \\
(0.0275)\end{array}$ & $\begin{array}{l}-0.0305 \\
(0.0463)\end{array}$ & $\begin{array}{l}0.0213 \\
(0.0248)\end{array}$ \\
\hline SD Temperature & $\begin{array}{l}1.2028 \\
(0.7567)\end{array}$ & $\begin{array}{c}4.4017 * * * * \\
(1.0173)\end{array}$ & $\begin{array}{l}-1.0373 \\
(1.1732)\end{array}$ & $\begin{array}{r}-1.6859 * \\
(0.7733)\end{array}$ \\
\hline Distance to road & $\begin{array}{c}- \\
0.0017 * * * \\
(0.0004)\end{array}$ & $\begin{array}{l}-0.0005 \\
(0.0004)\end{array}$ & $\begin{array}{l}-0.0006^{* *} \\
(0.0003)\end{array}$ & $\begin{array}{l}-0.0023 * \\
(0.0012)\end{array}$ \\
\hline $\begin{array}{l}\text { Extension } \\
\text { officer }\end{array}$ & $\begin{array}{r}0.0050 \\
(0.1332)\end{array}$ & $\begin{array}{l}0.1349 \\
(0.1395)\end{array}$ & $\begin{array}{l}0.0167 \\
(0.1907)\end{array}$ & $\begin{array}{l}0.1823 \\
(0.1247)\end{array}$ \\
\hline $\begin{array}{l}\mathrm{N} \\
\mathrm{R}^{2}\end{array}$ & $\begin{array}{l}771 \\
0.3279\end{array}$ & $\begin{array}{l}511 \\
0.1709\end{array}$ & $\begin{array}{l}534 \\
0.1544\end{array}$ & $\begin{array}{l}438 \\
0.3284\end{array}$ \\
\hline
\end{tabular}

Note: $* * *, * *$ and $*$ indicate significance of the estimated coefficient at $1 \%, 5 \%$ and $10 \%$, respectively. OLS estimation is in column (1) to (4). Robust standard errors are used.

The results indicate that the rainfall indicator used reveals a negative effect on food security of the household. In other words, increasing the variability of rainfall has a negative effect on current household food security. Household size and distance to the main road were found to negatively impact food security at the $1 \%$ level (Table 2 column 1 ). On the other hand, from all of the variables identified to influence food security, the area cultivated, access to credit, the education level of the family members, as well as the age of the household head, were found as 
Vol. 5, No. 02; 2020

ISSN: $2456-8643$

the main factors that affect a household's capability to improve their food security at the $1 \%$ level (Table 2).

Furthermore, by adding each indicator of food security, we examined the factor determinants on availability, accessibility and stability food of the household over time (column $2-4$ ). The result shows that the variability of rainfall measuring through the deviation over the years is the main factors, which harm food security, reducing $33 \%$ and $15 \%$ respectively the capability of the household to ensure food availability and stability of food over time column (2) and (4). In contrast, the mean temperature in range $230 \mathrm{C}-240 \mathrm{C} /$ year (Figure 1) found positively increased $40 \%$ food availability, indicates that the variation of temperature still in range for growing food production (maize, rice, cassava, etc.) that we measured for the food availability of the household. However, it negatively affects the stability of food for an increasing degree of temperature. This implies, in general, the climate has a negative effect that will pose uncertainty on food production, particularly for the sample household, which depends on the climate condition (rain-fed agriculture) for their agricultural activities. This will lead to the fluctuation on agricultural productivity that will reduce the household's income and the capability to fulfill their basic need.

Meanwhile, as expected area cultivated positively related with the welfare, concerning the important role of agriculture for the household, the increasing area cultivated tends to improve the availability, accessibility and the stability food of the household over time at $1 \%$ level confidence. Similarly, characteristics household which male-headed in the productive age and level education of the family member were found as factors improving accessibility and stability food of the households during the years. However, a part of this characteristic, household size within average 6 members was found the main factor that renders household to become foodinsecure due to high dependency at the $1 \%$ level confidence level.

Furthermore, we examined to what extent climate variability affects food security through a fixed-effect model, which controls for effects from unobserved household characteristics, as the Hausman-test confirmed that the model is appropriate in explaining factors determining the food security of a household in the research area. However, since the data set used is rather small (three years panel data set) and to avoid biased estimations due to relying on only withinhouseholds variation, therefore the result combined with the random effects estimator to solve this problem and applied the estimator within and between household variations. The same procedure proposed by Klasen et al. (2013), where they are measuring the income dynamics of cash crop choice in rural areas in Indonesia. The results using FE and RE are reported in Table 3.

The results indicate that climate negatively impacts household food security. A higher intensity of mean rainfall, which fluctuated in the range of $3.67-5.22 \mathrm{~mm} /$ month (Figure 2), as well as an average mean temperature of $24^{\circ} \mathrm{C}$, which deviates between $0.76^{\circ} \mathrm{C}$ to $0.89^{\circ} \mathrm{C}$ (Figure 1) monthly, has caused households to fall into a condition of insecurity during the period. The household's farm is rain-fed; this has a high-correlation with climate conditions. Thus, this climate variability on mean rainfall and temperature threatens the welfare condition of the household, reducing it to 43.32 and 18.01 respectively level food secure of the household. This finding is in line with the FAO (2008) reported that household food system negatively affected by climate change, in particular as results of gradual changes in mean temperature and rainfall. 
International Journal of Agriculture, Environment and Bioresearch

Vol. 5, No. 02; 2020

ISSN: $2456-8643$

Table 3. Climate effect to the food security of the household

\begin{tabular}{|c|c|c|}
\hline \multirow[t]{3}{*}{ Variable } & \multicolumn{2}{|l|}{ Food Security } \\
\hline & FE & $\mathrm{RE}$ \\
\hline & (1) & (2) \\
\hline \multirow[t]{2}{*}{ Age } & 0.0235 & $0.0085^{* *}$ \\
\hline & $(0.0441)$ & $(0.0045)$ \\
\hline \multirow[t]{2}{*}{ Sex } & $0.1112^{*}$ & 0.0188 \\
\hline & $(0.0597)$ & $(0.0397)$ \\
\hline \multirow[t]{2}{*}{ Household size } & $-0.2092 * *$ & $-0.0886^{* * *}$ \\
\hline & $(0.0865)$ & $(0.0320)$ \\
\hline \multirow[t]{2}{*}{ Number of men } & -0.1095 & -0.0626 \\
\hline & (0.2096) & $(0.0797)$ \\
\hline \multirow[t]{2}{*}{ Dependency ratio } & 0.1279 & -0.0411 \\
\hline & $(0.2193)$ & $(0.0926)$ \\
\hline \multirow[t]{2}{*}{ Maximum education } & 0.1239 & $0.1278 * * *$ \\
\hline & $(0.1543)$ & $(0.0351)$ \\
\hline \multirow[t]{2}{*}{ Access to Credit } & -0.0185 & $0.0417 * *$ \\
\hline & $(0.0533)$ & $(0.0162)$ \\
\hline \multirow[t]{2}{*}{ Area Cultivated } & $0.0014 * *$ & $0.0014 * * *$ \\
\hline & $(0.0006)$ & $(0.0002)$ \\
\hline \multirow[t]{2}{*}{ Mean Rainfall } & 0.0243 & $-0.1801 * * *$ \\
\hline & $(0.1552)$ & $(0.0552)$ \\
\hline \multirow[t]{2}{*}{ Mean Temperature } & $-0.4331 *$ & 0.0064 \\
\hline & $(0.2521)$ & $(0.0255)$ \\
\hline Distance to road & - $0.0048 *$ & $-0.0014 * * *$ \\
\hline
\end{tabular}


International Journal of Agriculture, Environment and Bioresearch

Vol. 5, No. 02; 2020

ISSN: $2456-8643$

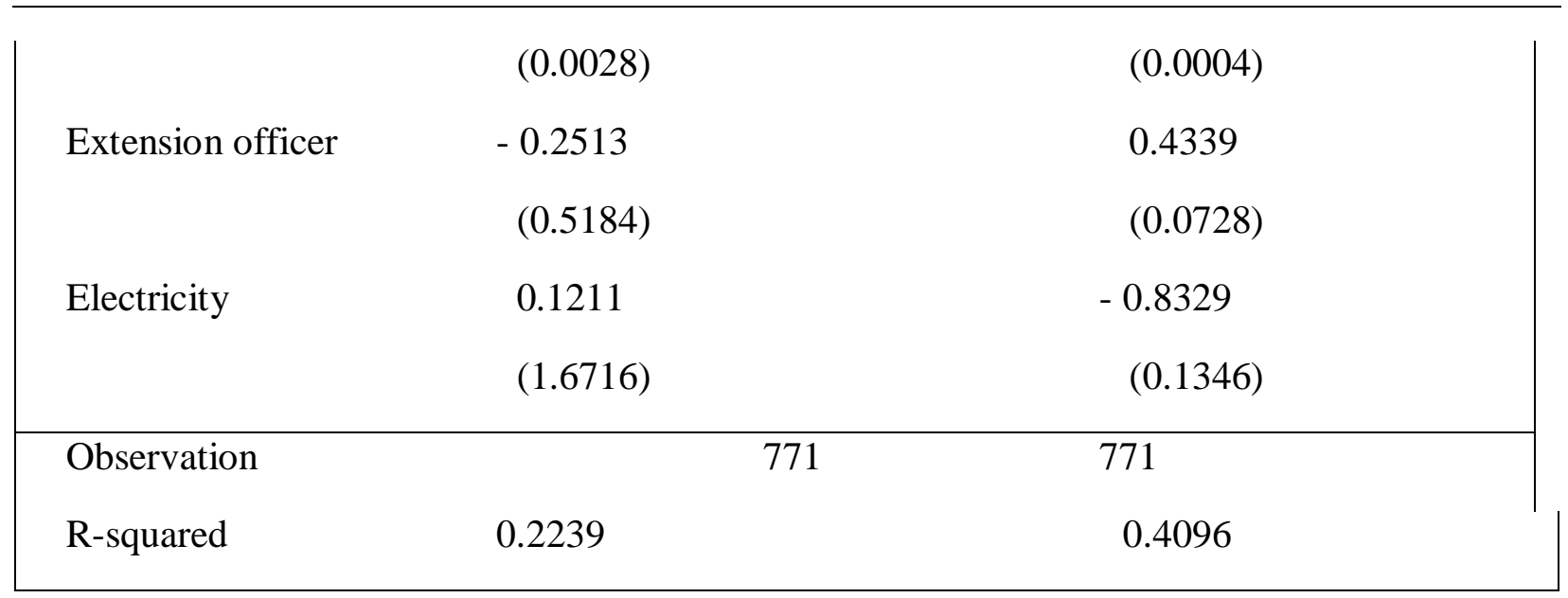

Source: Author's calculation based on survey data. Standard errors are in parentheses, $* * *, * *$, and $*$ are significant at $1 \%, 5 \%$, and $10 \%$ levels respectively. Robust standard errors are used.

Moreover, the negative sign of the household size is in line with expectations, as indicated by the fact that households with a high number of family members (around 6), has put the family at risk of being unable to meet their basic food needs. High responsibility to feed family members with the same source of income decreases the family's food security. Likewise, the distance to a road negatively influenced the food situation of the household. Concerning most of the households living in rural areas, the travel time to the main road became a barrier to the financial situation of the family, creating a condition of food insecurity. However, throughout the period, having a cultivated area of around 209.43 it tends to help people improve their food situation by around 0.18 and by 0.19 for every extension on area cultivation. Similarly, male-headed households with a male head being in productive age (46.26 years) brought the higher ability to the household to manage their family, which promoted the status of the family's food security (Table 3).

Overall, these results imply the important role of the cultivated area as a source for generating income, food and draft power for crop cultivation, as well as the household's age, and maximum education as an important proxy for a host of improvement capabilities. These capabilities, in turn, enable the household to bear the risks of income and food production, to ensure food security for the family. Conversely, the results also imply that substantial effort is necessary to mitigate the effect of climate variability and household size to escape the risk of being food insecure.

\section{CONCLUSIONS}

The results present the fact that area cultivated, as well as access to credit; age and the maximum education of family members are the main factor determinants of a household's food security in the study area. Whereas, household size and the variability of rainfall and temperature have a statistically significant negative effect on rural households and tend to reduce food security. Furthermore, a specific variability of rainfall significantly decreases the availability and stability of food over time by $33 \%$ and $15 \%$, respectively. The results also suggest that public services on health, education and infrastructure need to be strengthened, investments in access to credit and 
Vol. 5, No. 02; 2020

ISSN: $2456-8643$

off-farm employment policies, as well as insurance programs on social protection and disaster management, need to be developed to help mitigate these problems.

This research is a continuation of previous research by Asih and Klasen (2017) with the limitations of research using household panel data in 2001, 2004, and 2006 in assessing the impact of climate change on food security in Indonesia.

\section{REFERENCES}

Asih, D. N., \& Klasen, S. (2017). Improving food security ? Setting indicators and observing change of rural household in Central Sulawesi. Forest and Society, 1(November), 154-161.

Benson, C., Clay, E., 1998. The impact of drought on Sub-Saharan African economies. World BankTechnical Paper No. 401. The World Bank, Washington.

Demeke, A.B., Keil, A., Zeller, M., 2011. Using panel data to estimate the effect of rainfall shocks on smallholder's food security and vulnerability in rural Ethiopia. Climatic Change (108) 185-206.

Filmer D., Pritchett L., 1998. Estimating wealth effects without expenditure data -- or tears: An application to educational enrolments in the States of India, World Bank Policy Research Working Paper No. 1994

Food And Agriculture Organization, 2008. Climate Change And Food Security: A Framework Document. Food And Agriculture Organization Of The United Nations, Rome.

Food and Agricultural Organisation, 2008. Challenges For Sustainable Land Management For Food Security In Africa. In: 25th Regional Conference for Africa. Nairobi Kenya: pp: 15.

Intergovernmental Panel on Climate Change, 2014: Summary for policymakers. In: Climate Change 2014: Impacts, Adaptation, and Vulnerability. Part A: Global and Sectoral Aspects. The contribution of Working Group II to the Fifth Assessment Report of the Intergovernmental Panel on Climate Change [Field, C.B., V.R. Barros, D.J. Dokken, K.J. Mach, M.D. Mastrandrea, T.E. Bilir, M. Chatterjee, K.L. Ebi, Y.O. Estrada, R.C. Genova, B. Girma, E.S. Kissel, A.N. Levy, S. MacCracken, P.R. Mastrandrea, and L.L. White (eds.)]. Cambridge University Press, Cambridge, United Kingdom and New York, NY, USA, pp. 1-32.

Klasen, S., J. Priebe., R. Rudolf., 2013. Cash Crop Choice and Income Dynamics in Rural Areas : Evidence for Post-Crisis Indonesia. Agricultural Economics 44(3), pp 349-364.

Measey, M., 2010. Indonesia: A Vulnerable Country in the Face of Climate Change". Global Majority E-Journal, 1(1), 31-45

Netherlands Commission for Environmental Assessment, 2015. Climate change profile Indonesia. The report in a cooperation between the Netherlands Ministry of Foreign Affairs (MFA), Ms. K. Warner and Mr. P. van de Logt (IGG) the Centre for Development Innovation (CDI) of Wageningen UR, Ms. M. Brouwer and Mr. A.J. van Bodegom the Netherlands Water Partnership (NWP), The Netherlands. 
Skoufias, E., Davis, B., de la Vega, S., 2001. Targeting the poor in Mexico: an evaluation of the selection of households into PROGRESA. World Development, 29(10): 1 769-1 784

Syaukat, Y., 2011. The Impact Of Climate Change On Food Production And Security And Its Adaptation Programs In Indonesia. J. ISSAAS Vol. 17, No. 1: 40-51.

Wooldridge J.M., 2002. Econometric Analysis of Cross Section and Panel Data. The MIT Press, Cambridge 